\title{
ONOMARADIN
}

Journal of linguistics, philology and translation

\section{Translating Prohibition in Arabic Poetic Lines into English}

\author{
Nida S. Omar \\ University of Mosul \\ Iraq
}

\section{(C) $($ (i) $\ominus$}

Nida S. Omar: Department of Iraqi Board/ Deanship, College of Medicine, University of Mosul, Iraq. | E-mail: nidaaso@uomosul.edu.iq 


\section{Abstract}

This study investigates the indirect meanings of prohibitive linguistic acts used in Arabic poetic lines. Prohibition has been an interest of Arab and English researchers. Arab researchers have focused on the indirect meanings of prohibition in the Quran without paying attention to its existence in poetic lines. When Arabic prohibitive poetic lines are translated into English, issues arise because of linguistic and, sometimes, cultural notions between two different languages. In this study, three research questions must be answered. (1) What are the indirect meanings of prohibitive poetic lines at the level of ideational meaning? (2) What are the types of the transitivity processes of prohibitive poetic lines in Arabic and English? (3) Which type of translation method is used in translating Arabic prohibitive poetic lines into English? On this ground, the study is based on Speech Act Theory by Searle (1976) to show how the language of the speech is organised to convey the meaning of the speaker to the hearer. Systemic Functional Linguistics by Halliday (1994) is also adopted to show how ideational function through prohibitive acts is communicated. Nida's model for translation is also adopted to show methods in translating Arabic prohibitive poetic lines into English. The study has contended that direct and indirect meanings occurred within the scope of Searle's classification. The process of prohibitive speech acts was subjected sometimes to change when translated into English. The present study has also exposed how the indirect meaning of Arabic prohibitive poetic lines is generally conveyed by formal translation and, sometimes, by dynamic translation and by both.

Keywords: Arabic; transitivity; speech acts; prohibition; poetic line. 


\section{Introduction}

Poetry usually makes use of certain influential words and utterances to transfer particular ideas and passions. Words and utterances are usually normal although they might be difficult or uncommon due to their usage in an unfamiliar way (King, 1998: 14-15). Poems are arranged in short or long verses that have a consistent rhythm to create musical effects (King, 1998: 19 and 27).

Understanding the meaning that the speaker wants to stress is achieved through analysing semantic components and intention. The intention of the speaker is offered explicitly or implicitly. Prohibition is a negative imperative formula implying a request from superiority to deprive the addressee from doing a particular action. Imperative prohibition is the reverse of imperative. Although both formulas imply a request, an imperative is a request to perform a particular action, whereas imperative prohibitive is a request not to perform a particular action (Al-Malik, 1995: 80-81). Prohibition is an important element in all languages. It is a semantic, grammatical and pragmatic element that exists in Arabic and English Ianguages. Arabic and English make use of the negative formula to express prohibition, but its indirect meaning remains implicit and requires effort from the hearer or reader to infer it. Prohibition makes use of the negative form to express various types of indirect meanings, such as a reproach, wish, appeal, advice, regret and rebuke. Obtaining the indirect meanings of prohibition may be problematic in translation because the translator must know the speaker's intention. Simply, prohibition is a negative imperative formula whose meaning implies a request not to do a particular action. For instance, 'لا تسرع اثناء قيادة السيارة la tusric athna qiyadat al-sayyarah / don't hurry while driving the car.' If the speaker has a desire to advise the hearer, the speaker would say ، لا تسرع اثناء قيادة السيارة، فهذا يعرضك للخطر / la tusric athnaº qiyadat al-sayyarah, fahatha u'ariduka lilkhatar / don't hurry while driving the car, it is dangerous to you.' The translator must be aware of such additional information and attempt to convey the correct intention of the speaker to the hearer or reader. Such additional information is important because it implies the indirect meaning of the speaker. Similarly, prohibitive speech acts in English have various indirect meanings built on their context, such as 'don't go to the river my son; it is deep.' The prohibitive formula 'Don't go' is free of obligation, but warns his son from going to the river because it is deep. Again, the translator must be aware of the additional information 'it is deep,' which gives a good clue that the intention of the speaker is to warn his son and not to oblige him.

Hence, the present study tries to concentrate on analysing prohibition in poetic lines because it implies various indirect meanings that must be studied via translation into English. The present study provides simple standards for translators who are interested in discovering the indirect meanings of prohibition in literary poems. Such standards offer comparative facets of translating Arabic prohibition in poetic lines and their translation in English. 


\section{The Concept of Prohibition in Arabic}

People occasionally use indirect speech to make their speech pleasant and lovely or when they want to strengthen the message that they convey to the hearer (Thomas, 1995: 143). In Arabic language, Arab poets tend to use indirect speech in poems for certain goals. The meaning of the indirect speech acts depends on the intent of the speaker and the context in which they occur. Prohibition in Arabic is one of the styles used indirectly to communicate the message to the hearer.

Generally, prohibition is a request for the hearer to stop doing a particular action in a negative form (Cabbas, 1989: 154). It is realised by the present tense in jussive mood preceded

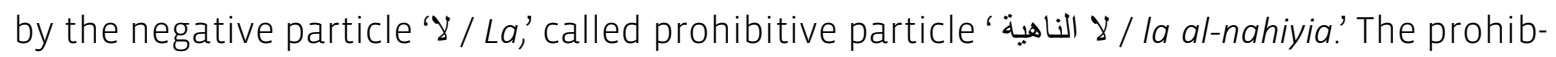
itive particle ' لا الناهية / la al-nahiyia' is used to (1) order the addressee who is doing an action at the moment of speaking (2) and to order the addressee who is not doing an action at the moment of speaking (ibid.). The basic meaning of prohibition sometimes deviates from its direct meaning to indirect meaning which could be inferred from the context. Other indirect meanings are advice, reproach, appeal, wish, regret and rebuke.

Jumca (2005) highlights that a prohibition is a negative form implying imperative, but it significantly differs from imperative. An imperative is a request usually for the hearer to do a particular action. By contrast, the prohibition asks the hearer not to do a particular action. He adds that another crucial difference between prohibition and imperative is that the former implies unpleasant action, whereas the latter means an obligation. Therefore, prohibition is a request for the hearer not to do an unpleasant action. Prohibition is divided into two main types: basic and non-basic prohibitions. Basic prohibition implies direct meaning, whereas non-basic prohibition implies indirect meaning (p. 122). The indirect meanings of prohibition depend on the context.

\section{The Concept of Prohibition in English}

Prohibition is a directive speech act where the addresser deprives the addressee from doing some actions (Allan, 1986). Similarly, Bach and Harnish (1979) affirm that a prohibitive sentence is a request and that speech acts implying prohibition reveal the intention of the addresser whether it is a desire or a wish (p. 47). Prohibition occurs at a syntactic, semantic and pragmatic level. Syntactically, Swan (2000) infers that prohibitive sentences are negative imperatives that usually begin with 'do not,' followed by a simple verb. They are used to inform the addressee to not do a particular action according to the addresser's implied request. Quirk et al. (1985) corroborate that prohibition can be expressed by using block language expressions, such as headlines of newspapers, labels and advertisements, which take the form of a noun phrase prefixed by 'no,' such as 'no entry.' Semantically, prohibition could be expressed by using modality, that is, auxiliary verbs, which imply such meanings as permission, obligation 
and prohibition, as in 'students must not use phones in the class'. On a pragmatic level, prohibition could be expressed using prohibitive performative speech acts, such as 'forbid and prohibit,' which express the addresser's desire for the addressee to fulfil the state of affairs conveyed in the proposition (Al-Saaidi et al., 2013: 97-98). According to illocutionary force, the speech act determined by proposition is in the attention of the addressee. The addresser attempts to present his/her own attention as being useful to the addressee. However, prohibitive speech acts can be used to convey different illocutionary forces, such as threatening, forbidding, wondering and advice and guidance (Al-Saaidi et al., 2013: 98). For instance, 'do not open the window; it is cold.' In this example, the addresser does not order the addressee but appeals to him because it is cold. Apparently, various indirect meanings of prohibition are built on their context similar to prohibition in Arabic.

\section{Theoretical Framework}

The present study adopts a qualitative approach to fulfil its aims. Some poetic lines that entail prohibitive sentences have been chosen for various Arab poets. Data are examined on the basis of Speech Act Theory by Searle (1976) and Transitivity Model within the frame of Systemic Functional Linguistics by Halliday (1994). Data are also examined on the basis of Nida's concept of translation equivalence to find out which type of translation is chosen in translating Arabic prohibitive poetic lines into English. All chosen methods are summarised as follows.

\subsection{Speech Act Theory (Searle, 1976)}

Pragmatic analysis of language examines the meaning of an utterance derived from the way the utterances are used and not from the formal merits of the constructions or words (Leech, 1981). The study of language focuses on the meaning of the utterances, rather than on a grammatical sentence or a proposition (Wales, 2001 [1989]: 365). Hence, pragmatics are concerned with the meaning of the words conveyed when they are used or with intended speaker meaning, as it is sometimes referred to (Wisniewski, 2007).

Pragmatic theories and speech act theory mainly pertain to how the speaker and the hearer understand each other regardless of the possibilities of their speech (Ayemoni, 2005). Illocutionary acts are complicated because they connect with the intent of the speaker and the context in which they take place, such as requesting, threatening and promising. Searle (1976: 10-16) suggests five main types of speech acts which might be used by the speaker.

1) Assertive acts express the speaker's intent, such as describe, claim and predicate.

2) Declarative acts change the world, such as 'I bet,' 'I declare' and 'I resign.'

3) Acts of commitment obligate the speaker to future actions, such as vowing, threatening, promising and referring. 
4) Directives acts oblige the hearer to do something, such as request, invite, suggest, forbid and command.

5) Expressive acts clarify what the speaker feels, such as apologise, deplore, praise and regret.

\subsection{Transitivity Model (Halliday, 1994 [1985])}

In systemic functional linguistics, language is communicated to text structure, that is, the function and meaning of language, because language as a social phenomenon is functional. Meaning is principal in systemic functional linguistics performed through linguistic choices of discourse where words and sentences are organised in a clause or text. Halliday presents a valuable linguistic model represented by the transitivity model that determines the fundamental linguistic features of a particular literary discourse. Halliday makes use of discourse to investigate communication via linguistic features (cited in Munday, 2008: 90). These linguistic features befall obvious in the discourse or text via lexical-grammatical components like modality, cohesion and transitivity. The lexical-grammatical components are in turn manipulated by three metafunctions: ideational, interpersonal and textual.

Ideational function deals with grammatical structures at a clausal level and is expressed using the transitivity system, whereas interpersonal function deals with a topic of information and it is expressed using mood structures at a clausal level. Textual function deals with a theme at a clausal level; it is expressed using theme and rheme structures. Transitivity is considered a main component in the ideational function at the level of the clause. It deals with the spread of ideas signifying processes, actions, events and processes of relations and consciousness (Halliday, 1994 [1985]: 53).

Transitivity is regarded as a useful grammatical tool for obtaining expertise in language. It indicates how meaning is implemented in the clause (Simpon, 2004: 22). Generally, transitivity involves three main processes: (a) process, (b) participants and (c) circumstances. The process is a fundamental element in the clause usually realised by a verb phrase. Halliday (1994 [1985]) attempts to classify process into various types involving material, mental, relational, verbal, behavioural and existential. Material process involves the action of happening and doing. Mental process involves the action of sense. Verbal process involves the action of (in) direct reporting. Behavioural process involves the action of psychological and physiological behaviours. Existential process includes the action of existing that refers to something occurring or existing.

The transitivity model is valuable because it enables researchers to analyse and signify the similar event and situation in various ways. It also provides ways of discovering how a particular linguistic action of a text determines a certain ideological viewpoint of a speaker or reader. 


\subsection{Translation Method (Nida, 1964)}

Nida looks at translation from a scientific viewpoint. He suggests two types of translation equivalence: formal and dynamic. Formal equivalence draws on the form of the message. Thus, the message of the target language must correspond as closely as possible to various elements from the source language (Nida, 1964: 159). Formal equivalence to a certain degree reveals the linguistic elements of the source language, such as grammar, syntax, vocabulary and structure, which have a considerable effect on the correctness of translation. Dynamic equivalence draws on the effect of equivalence on the receiver. Nida states that the relationship between the message and the receiver of the target language should be mainly similar to what occurs between the message and the source language receiver. Dynamic equivalence depends on the context and the sense-for-sense translation (1964: 159). In addition, dynamic equivalence draws not so much on the message of the source language but on the response of the receiver (Nida, 1964, 1966). In the same vein, cultural factor not only plays an important role in translating religious text, but also extends to all types of translation. Nida has confirmed that cultural differences, such as religious beliefs, customs, geographical locations and histories, affect reproducing natural equivalents in the target language. Therefore, translation does not only encompass linguistic competence of a translator, but also encompasses cultural knowledge. Furthermore, Nida asserts that suitable translation has four main requirements: producing a sense, transferring the manner and the spirit of the text, owing to a natural and simple form of expression and making a comparable response (1964: 164).

Linguistic method deals not only with the structure of the language, but also with the way language is used and its relation with the social context. On this basis, the present study draws on Nida's concept of translation.

\section{Methodology}

\subsection{Research Material}

The data of the present study were gathered from varied authentic sources. Six selected poetic lines have been supplied with English translations done by the researcher. The selected data with their English translation have been analysed using multi-methods: Speech Act Theory, Transitivity Model and Nida's model of translation. Focus has been directed towards the indirect meaning of prohibition in the Arabic literary language, particularly Arabic poetic lines, by analysing data within the frame of the mentioned multi-methods.

\subsection{Research Procedures}

The present study was conducted via multi-methods: Speech Act Theory, Transitivity Model and Nida's model of translation. The study is based on analysing the meaning of linguistic 
acts of six Arabic lines selected from various Arabic poems. All selected data with their English translation were compared. The selected data were analysed in terms of the canons of Searle's classifications to determine various types of Arabic prohibitive speech acts in poetic lines. Analysis of the selected data was achieved in terms of the transitivity concept of Halliday to reveal the type of process of prohibitive action in Arabic and English. The prohibitive poetic lines were also analysed in terms of Nida's model of translation. The translated English poetic lines were analysed to determine how the indirect meaning of prohibitive action is translated into English within the room of formal and dynamic translation.

\subsection{Analysis of Data and Discussion}

The data analysed the meaning of the linguistic acts of Arabic poetic lines qualitatively. The analysis of the selected data has been done within the tenets of the different models of various remarkable linguists.

$\operatorname{Data}(1)$

ST (1) لاتنه عن خلق وتاتي مثله عار عليك اذا فعلت عظيم (Abu al-Aswad al-Duªli)

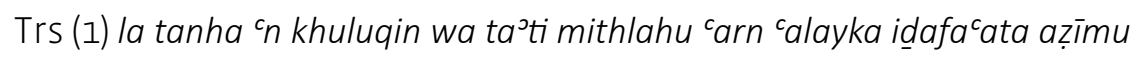

TT (1) Don’t behave against what you say

What a shame on you if you do that

\begin{tabular}{cccccc}
\hline $\begin{array}{c}\text { Prohibitive } \\
\text { act }\end{array}$ & $\begin{array}{c}\text { Type of direct } \\
\text { meaning }\end{array}$ & $\begin{array}{c}\text { Type of indirect } \\
\text { meaning }\end{array}$ & $\begin{array}{c}\text { Type of process } \\
\text { of Arabic act }\end{array}$ & $\begin{array}{c}\text { Type of process } \\
\text { of Englishact }\end{array}$ & $\begin{array}{c}\text { Type of } \\
\text { translation }\end{array}$ \\
\hline $\begin{array}{l}\text { لاتنه Don't } \\
\text { behave }\end{array}$ & $\begin{array}{c}\text { Directives- } \\
\text { request }\end{array}$ & $\begin{array}{c}\text { Expressive- } \\
\text { reproach }\end{array}$ & Verbal & Behaviour & Dynamic \\
\hline
\end{tabular}

The above example implies a reference to people whose deeds are against what they say. The poet considers such bad behaviour shameful. The prohibition formula 'لاتته / la tanha' does not carry the main intention of the poet. In a sense, the poet does not ask the adوتناتي منله' dressee to stop behaving but rebukes him/her. Therefore, he adds information . ع عار عليك اذا فعلت عظيم... / wa ta’ti mithlahu ... 'arn 'alayka idafacata azīmu' to transfer his intention.

Within Searle's classification of speech acts, the meaning of the Arabic prohibitive speech act 'لاتته/ / la tanha' is altered from direct meaning request-directives into expressive-reproach. Both are listed in Searle's classification.

In the field of transitivity system, the Arabic prohibitive form 'لاتنه / la tanha / don’t behave' is a verbal process; it literally means 'don't prohibit.' It has changed into a behavioural process when translated into English. In addition, the second Arabic verb 'وتاتي مثلك، / wa tati mithlahu' is an affirmative and means 'behave.' It has changed into the verb 'say.' 
Apparently, the first part of the poetic line 'لاتنه عن خلق / la tanha 'n khuluqin / Don't behave' implies the meaning of saying which has altered into a verb. Moreover, the second part of the first poetic line 'وتاتي متلك / wa ta’ti mithlahu' involves behaviour, which has altered into the verb 'say.' This alteration leads to dynamic translation. Dynamic translation shows that it has rendered the intended meaning of the poet. It has also managed to convey Arabic culture, which is consistent with English culture.

$\operatorname{Data}(2)$

ST (2) اذا ماشئت ان تحيا حياة حلوة المحيا فلا تحسد ولاتبخل ولاتحرص على الدانيا (2Ali Ibin Abi Talib)

Trs (2) Ida mashta an tahya hayatan hulwata almahya fala tahsd wa la tabkhal wa la tahrec ala aldunia.

TT (2) If you want to live a lovely life,

\section{Don't envy, don't be stingy, and} Don't be so greedy of mankind for life.

\begin{tabular}{|c|c|c|c|c|c|}
\hline $\begin{array}{c}\text { Prohibitive } \\
\text { act }\end{array}$ & $\begin{array}{l}\text { Type of direct } \\
\text { meaning }\end{array}$ & $\begin{array}{l}\text { Type of indirect } \\
\text { meaning }\end{array}$ & $\begin{array}{c}\text { Type of process } \\
\text { of Arabic act }\end{array}$ & $\begin{array}{l}\text { Type of process } \\
\text { of English act }\end{array}$ & $\begin{array}{c}\text { Type of } \\
\text { translation }\end{array}$ \\
\hline $\begin{array}{c}\text { / دسحتت ال / } \\
\text { don't envy }\end{array}$ & $\begin{array}{l}\text { Directives- } \\
\text { request }\end{array}$ & $\begin{array}{l}\text { Directives- } \\
\text { advice }\end{array}$ & $\begin{array}{l}\text { Emotive- } \\
\text { mental }\end{array}$ & $\begin{array}{l}\text { Emotive- } \\
\text { mental }\end{array}$ & Formal \\
\hline $\begin{array}{l}\text { be stingy } \\
\text { be الاتخ'don't }\end{array}$ & $\begin{array}{l}\text { Directives- } \\
\text { request }\end{array}$ & $\begin{array}{l}\text { Directives- } \\
\text { advice }\end{array}$ & $\begin{array}{c}\text { desiderative- } \\
\text { mental process } \\
\text { + behavioural } \\
\text { process }\end{array}$ & $\begin{array}{l}\text { attributive } \\
\text { process- } \\
\text { relational } \\
\text { process }\end{array}$ & \\
\hline $\begin{array}{l}\text { / لا تحرص/t } \\
\text { don't be so } \\
\text { greedy }\end{array}$ & $\begin{array}{l}\text { Directives- } \\
\text { request }\end{array}$ & $\begin{array}{l}\text { Directives- } \\
\text { advice }\end{array}$ & $\begin{array}{c}\text { desiderative- } \\
\text { mental process } \\
\text { + behavioural } \\
\text { process }\end{array}$ & $\begin{array}{l}\text { attributive } \\
\text { process - } \\
\text { relational } \\
\text { process }\end{array}$ & \\
\hline
\end{tabular}

The poetic line includes a request from the speaker to the addressee in the form of prohibition. The speaker does not intend to send his request to the addressee but to advise him. Thus, the ideational function is slightly affected when translated into English due to changes at the level of transitivity process.

The Arabic prohibitive verbs ‘لا تحسد / la tahsd / don’t envy, لاتبخد / la tabkhal / don't be stingy, /لا تحرص /a tahrec/don't be so greedy' are in the present tense, prefixed by the prohibitive particle ' $\gamma$ ' and refers to the basic meaning of prohibition. The speaker does not request the addressee

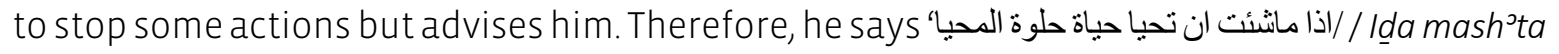
an tahya hayatan hulwata almahya / if you want to live a lovely life.' Therefore, the speaker clarifies that a pleasant life requires getting rid of bad qualities, such as envy, stinginess and greed.

With respect to speech acts, the speech act is changed from the direct meaning of request into the indirect meaning of advice to match Searle's types, that is, directives. 
In the field of the transitivity system, the Arabic prohibitive verb 'ע / لحسد / la tahsd / don't envy' is a mental process because it has an emotional sense. It is rendered into 'don't envy,' which also belongs to the emotive-mental process. Commonly, the mental process involves sensation. It involves perception, desire, cognition and emotion (Halliday \& Mattiessen, 2014); thus, the process in Arabic and English has been similarly sustained.

The Arabic prohibitive verbs 'لاتبخل / la tabkhal / don’t be stingy, لا تحرص / la tahrec / don't be so greedy' have behavioural and desiderative meanings, which belong to a mental process. They refer to an activity-sharing physiological and psychological quality. Hence, inner desire of stinginess and greediness reflects on the behaviour of a person who has this inner desire.

In terms of translation, both Arabic verbs ' لاتبخل/ la tabkhal / don't be stingy, لاتحرص / la tahrec / don't be so greedy' have translated into an attributive process that belongs to relational process; thus, the process of Arabic prohibitive verbs has not been sustained in the same way as in the English translation.

The source text is translated formally. It manages to convey the intention of the speaker with the slight change of meaning when the Arabic prohibitive verbs 'لاتبخل / la tabkhal / لا تحرص / la tahrec' changed from the mental-behavioural process into a relational process due to change from the present tense into an adjective. Arabic and English poetic lines engage the same cultural concepts; hence, formal translation has succeeded in sustaining the Arabic cultural concept into English.

Data (3)

ST (3) لا تعجبي ياسلُُ من رجلٍ ضحك المشيبُ بر اسه فبك (Dacbul Al-Khuzacy)

Trs (3) la tacjabi ya Salmu min rajulin dahika al-mashibu bi ra ${ }^{\circ}$ sihi fa baka

TT (3) O Salm! Don't be astonished of a man,

Whose head is covered with grey hair, then cried.

\begin{tabular}{cccccc}
\hline $\begin{array}{c}\text { Prohibitive } \\
\text { act }\end{array}$ & $\begin{array}{c}\text { Type of direct } \\
\text { meaning }\end{array}$ & $\begin{array}{c}\text { Type of indirect } \\
\text { meaning }\end{array}$ & $\begin{array}{c}\text { Type of process } \\
\text { of Arabic act }\end{array}$ & $\begin{array}{c}\text { Type of process } \\
\text { of English act }\end{array}$ & $\begin{array}{c}\text { Type of } \\
\text { translation }\end{array}$ \\
\hline لانعجبdon't & $\begin{array}{c}\text { Directives- } \\
\text { request }\end{array}$ & $\begin{array}{c}\text { Expressive- } \\
\text { admiration }\end{array}$ & Mental-emotive & Mental-emotive & $\begin{array}{c}\text { Formal and } \\
\text { dynamic }\end{array}$ \\
\hline
\end{tabular}

The direct meaning is a request from the speaker to the hearer. The speaker uses prohibition to convey his admiration to a particular matter that worries all people, which is greying hair. The ideational function of the poetic line has been kept the same in its English translation.

The poet presents a positive perspective to the matter of greying hair. He speaks to his sweetheart and asks her not to admire a man whose hair is covered with grey hair. 
He makes use of the Arabic prohibitive verb 'لا تعجبي / la tacjabi / don't be astonished' to express his admiration. Indirect meaning of admiration is within the circle of Searle's types of speech acts, that is, directives. In the same vein, the poet confirms his adضحك المشيب miration and provides an alliteration in the second part of the poetic line d dahika al-mashibu bi rasihi fa baka,' which literally means 'the grey hair laughs at his head, then cries / His head was covered with grey hair, then cried.' In addition, the poet makes use of opposition represented by 'ضحك / dahika,' which literally means 'laugh at' and 'بكى/baka/ cry.' The second part of the poetic line reflects an evident change during translation because d dahika al-mashibu bi rasihi,' which means literally 'the grey hair laughs at his head,' is unfamiliar and unacceptable in the English language. Cultural variance between Arabic and English has been considered and translated into 'his head was covered with grey hair, then cried.' Consequently, translation of the second part of the poetic line is dynamic. Dynamic translation manages to convey the intended meaning of the poet, and sustains cultural nuance of the Arabic poetic line in English.

In terms of the network of transitivity, the Arabic prohibitive verb 'لا تعجبي / la tacjabi / don’t be astonished' is an emotive process and belongs to the mental process. It has been sustained the same in the English translation.

Rendering of the Arabic poetic line provides an example of bilateral translation (formal and dynamic); the cultural aspect has been sustained in the English translation.

$\operatorname{Data}(4)$

ST (4) دع المكارم لاترحل لبغينها و اقعد فانك انت الطاعم الكاسي (al- Hutayª)

$\operatorname{Trs}(4) d^{c}$ almakarim la tarhal li bughyatiha wa $u q^{c} d$ fa inka anta alțacm al kasy

TT (4) Abandon the generosities do not leave to get it

Stay home since you are surely the one who feeds and dresses

\begin{tabular}{cccccc}
\hline $\begin{array}{c}\text { Prohibitive } \\
\text { act }\end{array}$ & $\begin{array}{c}\text { Type of direct } \\
\text { meaning }\end{array}$ & $\begin{array}{c}\text { Type of indirect } \\
\text { meaning }\end{array}$ & $\begin{array}{c}\text { Type of process } \\
\text { of Arabic act }\end{array}$ & $\begin{array}{c}\text { Type of process } \\
\text { of English act }\end{array}$ & $\begin{array}{c}\text { Type of } \\
\text { translation }\end{array}$ \\
\hline $\begin{array}{l}\text { Drdo } \\
\text { not leave }\end{array}$ & $\begin{array}{c}\text { Directives- } \\
\text { request }\end{array}$ & $\begin{array}{c}\text { Expressive- } \\
\text { contempt }\end{array}$ & $\begin{array}{c}\text { Material } \\
\text { process }\end{array}$ & $\begin{array}{c}\text { Material } \\
\text { process }\end{array}$ & $\begin{array}{c}\text { Formal and } \\
\text { dynamic }\end{array}$ \\
\hline
\end{tabular}

Direct meaning of the poetic line is a request from the speaker to the hearer. The Arabic prohibitive form 'لاترحل / la tarhal / don't leave' is in the present tense prefixed by the prohibitive particle ' $y$ ' and indicates the meaning of prohibition. The poet does not prevent the addressee from leaving, but disregards him/her. The poet also uses the imperative verb ' $2 َ / d c / a b a n d o n '$ at the beginning of the first part of the poetic line to confirm his contempt for the addressee. The additional information in the second part of the poetic line واقعد فانك انت الطاعم الكاسي wa $u q^{c} d$ fa inka anta alțac $m$ al kasy' confuses the reader. It shows that the poet praises the addressee. On the contrary, the real intention of the poet is to mock the addressee. 
According to Searle's taxonomy of speech acts, direct and indirect meaning of the Arabic prohibitive form 'لاترحل/ / la tarhal / don't leave' occurs within his classification where the meaning of the Arabic prohibitive form ' لاترحل / la tarhal / don't leave' changed from request to contempt.

In the same vein, the network of the transitivity system, the Arabic prohibitive form ' لاترحل / la tarhal / don't leave' is a material process in Arabic and English.

With regard to translation, rendering of the poetic line into English shows a simultaneous use of formal and dynamic translations. The cultural aspect has been lost in translation.

Data (5)

ST (5) أعيني جودا ولا تجمدا ألا تتكيان صخر الندا (al- Khanssa²)

Trs (5) a caynay juda wa la tajmada illa tabkiyan Sakhar al-nada

TT (5) O my eyes! Be generous and don't be stingy

So, cry bitterly the generous for Sakher.

\begin{tabular}{|c|c|c|c|c|c|}
\hline $\begin{array}{c}\text { Prohibitive } \\
\text { act }\end{array}$ & $\begin{array}{l}\text { Type of direct } \\
\text { meaning }\end{array}$ & $\begin{array}{l}\text { Type of indirect } \\
\text { meaning }\end{array}$ & $\begin{array}{c}\text { Type of process } \\
\text { of Arabic act }\end{array}$ & $\begin{array}{l}\text { Type of process } \\
\text { of English act }\end{array}$ & $\begin{array}{c}\text { Type of } \\
\text { translation }\end{array}$ \\
\hline $\begin{array}{c}\text { be stingy / لا جمدا don't } \\
\text { be sting }\end{array}$ & $\begin{array}{l}\text { Directives- } \\
\text { request }\end{array}$ & $\begin{array}{l}\text { Expressive- } \\
\text { wish }\end{array}$ & $\begin{array}{l}\text { Relational- } \\
\text { attributive }\end{array}$ & $\begin{array}{l}\text { Relational- } \\
\text { attributive }\end{array}$ & Dynamic \\
\hline
\end{tabular}

The poet expresses deep sadness in this poetic line; she mourns her dearest brother and focuses on the quality of generosity. At the beginning of the poetic line, she calls for her eyes ' أعيني جودا' a caynay juda / O my eyes! Be generous.' At the end of the poetic line, she describes her dead brother with 'الندا / al-nada,' which means 'the generous.' The direct meaning reflects that the poet asks her eyes to be generous with her because she is crying for her generous brother Sakher. The surface meaning of the poetic line reveals that the poet requests her eyes not to stop crying due to the death of her brother, who was so generous to her.

Prohibition appears to be addressed to an inanimate object. The Arabic prohibitive for-

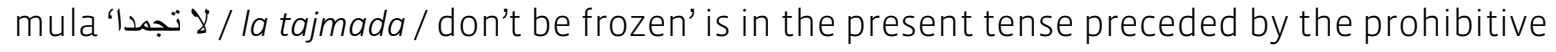

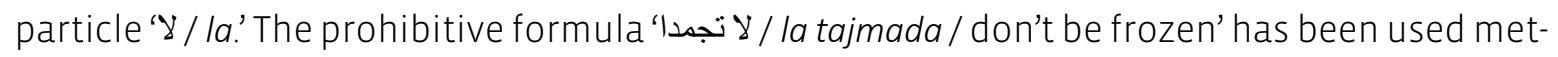
aphorically to show the meaning of 'stinginess.' The indirect meaning of the Arabic prohibitive formula 'لا تجمد/ / la tajmada / don't be stingy' conveys the wish of the poet to cry bitterly for her brother. Thus, the meaning of the Arabic prohibitive formula 'لا لجمد / la tajmada / don't be frozen' has changed during translation into English.

The direct meaning of the Arabic prohibitive speech ‘ لا تجمد/ /a tajmada / don't be stingy' is a request, whereas the indirect meaning is a wish. Both meanings are found within the scope of Searle's classification of speech acts. 
With regard to transitivity concept, the Arabic prohibitive formula ' لا تجمد/ la tajmada / don't be stingy' is a relational-attributive process, which remains the same when translated into the English 'don't be stingy.'

In the same vein, the Arabic prohibitive formula 'لا تجمد/ / la tajmada' has been translated dynamically. Dynamic translation somewhat succeeds in transferring the intended meaning of the poetic line, but the cultural aspect has been lost in translation.

Data (6)

ST (6) لا تحسبوا نأيكم عنا يغيرنا إنْ طالما غير النأيُ المحبين (Ibin Zaydwn)

Trs (6) la tahsabu nayakum 'ana yoghyuruna º țalama ghyara al nay almuhbina

TT (6) Don’t believe your departure will change me, Even though departure changes the feelings of lovers

\begin{tabular}{cccccc}
\hline $\begin{array}{c}\text { Prohibitive } \\
\text { act }\end{array}$ & $\begin{array}{c}\text { Type of direct } \\
\text { meaning }\end{array}$ & $\begin{array}{c}\text { Type of indirect } \\
\text { meaning }\end{array}$ & $\begin{array}{c}\text { Type of process } \\
\text { of Arabic act }\end{array}$ & $\begin{array}{c}\text { Type of process } \\
\text { of Englishact }\end{array}$ & $\begin{array}{c}\text { Type of } \\
\text { translation }\end{array}$ \\
\hline $\begin{array}{c}\text { Directives- } \\
\text { Don't believe }\end{array}$ & $\begin{array}{c}\text { Directives- } \\
\text { request }\end{array}$ & $\begin{array}{c}\text { Mental-cognitive } \\
\text { appeal }\end{array}$ & $\begin{array}{c}\text { Mental-cognitive } \\
\text { process }\end{array}$ & Formal \\
\hline
\end{tabular}

The poet expresses his feelings towards his sweetheart. He attempts to present an ideal picture of his love by saying that her departure will never change his feelings towards her. The Arabic prohibitive form ‘ لا تحسبو/ la tahsabu / don’t believe’ does not provide the meaning of appeal. The intended meaning of appeal exists clearly in the second part of the poetic line

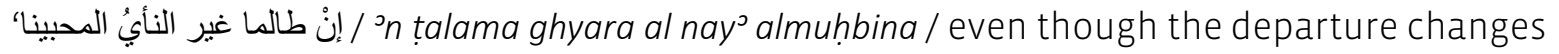
the feelings of lovers.'

The direct meaning of ' لע / لا تحسبو / la tahsabu / don't believe' is a request, and the indirect meaning is an appeal. Both meanings of ' 'لحسبو / / la tahsabu / don't believe' are within the scope of Searle's classification of speech acts.

On the part of transitivity system, the Arabic prohibitive verb 'لا تحسبو / la tahsabu / don’t believe' is a mental-cognitive process which remains the same during English translation.

In terms of translation, the formal translation of the poetic line could convey its intended meaning and keep its cultural aspect as well.

\section{Conclusion}

The present study focuses on Arabic prohibitive poetic lines and their English translation, which are analysed using Searle's (1976) Speech Act Theory, Halliday's (1994) Transitivity System and Nida's (1964) translation method. According to Searle's classification of speech acts, 
direct and indirect meanings of Arabic prohibitive poetic lines and their English translation are localised within Searle's classification.

In terms of the transitivity system, translation has generally sustained the process of the Arabic speech acts in English. Occasionally, changes have been done in the process of Arabic prohibitive speech acts when translated into English. In some cases, translation has affected the Arabic prohibitive process with a slight change in meaning. In other cases, the English translation manages to convey the suitable Arabic prohibitive process whilst keeping its original meaning.

According to Nida's (1964) translation theory, the concept of formal and dynamic transIation has been equally used in translating Arabic prohibitive poetic lines into English. In the same vein, bilateral translation (formal and dynamic) was necessary to other examples to convey the intended meaning of the Arabic prohibitive poetic lines.

The translation has also often kept the cultural concept in English translation, whereas, in some cases, the cultural concept has been affected or lost.

\section{References}

CabBAS, Fadel, 1989: Rhetoric, its Arts and its Branches (Semantics), Jordan: Dar Al-Furqan.

Al-Duªl, Abu al-Aswad, 1998: Diwan Abu al-Aswad al-Duªli, Beirut: Al-Hilal.

Allan, Keith, 1986: Linguistic Meaning, vol. 2, New York: Routledge and Kegan Paul, Inc.

Ayemoni, M. O., 2005: "Pragma-stylistic analysis of major general J.T aguiyi - ironsi's maiden speech", Awka Journal of Linguistics and Languages 1, 1-9.

BaCH, Kent, \& Robert Harnish, 1979: Linguistic Communication and Speech Acts, Cambridge: MIT Press.

Halliday, M. A. K., 1994 [1985]: An Introduction to Functional Grammar, London: Edward Arnold.

Halliday, M. A. K., \& Christian M. I. M. Matthiessen, 2014: An Introduction to Functional Grammar, London: Routedge.

Al-Hutayª, Jroul, 1993: Diwan Jroul Al-Hutayª, Cairo: Publishing of Scientific Books.

Ibn Zaydwn, Aḥmad, 1994: Diwan Ibn Zaydwn, Beirut: Al-kittab Al-cArabi Publishing.

Al-Khazralı, Abwd, (n. d.): Jmam `Ali Ibin Abi Talib, Baghdad: Scientific Library. 
Jumca, Hussein, 2005: The Beauty of Declarative and Non-Declarative, Damascus: Publishing of Arab Writers Union.

Al-KhansSA', Tamader, 1985: Diwan Al-Khanssa’, Cairo: Al-Saªda Publishing.

AL-KHuzAcy, Dcbul, 1994: Dbul Ibin ªli Al-Khuzacy, Lebanon: Al-Kittab Al-cArabi Publishing.

KING, John, 1998: Take a Lesson in Poetry, England: The publishing House.

LeECH, Geoffrey, 1981: Semantics, Harmondsworth: Middlessex Penguin Books.

LeEch, Geoffrey, \& Michael Short, 1981: Style in Fiction: A linguistic Introduction to English Fictional Prose, London and New York: Longman.

Leigh, James, \& Derek Stanbridge, 1991: Multicultural Communication, Intermeridian.

AL-Malik, Fahad M., 1995: Performative Utterances: Their Basic and Secondary Meanings with Reference to Five English Translations of the Meanings of the Holy Qur'an. Ph.D. Thesis, University of Durham in UK.

Maryam, Mannac, 2012: "Mustafa IBin Raḥmoon", Revues - Dakira 1 [available at www.revues-univ-ouargla.dz].

Munday, Jeremy, 2008: Introducing translation studies: Theories and applications, London: Routledge.

NidA, Eugene, 1964: Towards a Science of Translation, Leiden: E. J. Brill.

NIDA, Eugene, 1966: Principle of Translation, Oxford: Oxford University Press.

Osuala, P. Chinyere, 2009: "A Semio-stylistic Analysis of the Currency notes of Nigeria and the United States of America”, B.A. Long Essay, Department of English, Redeemer's University, Ogun State.

Quirk, Randolph, Sidney Greenbaum, Geoffrey Leech \& Jan Svartvik, 1985: A Comprehensive Grammar of the English Language, London: Longman Group Limited.

Al-SaAidI, Sawsan, Ghayth Al-Shaibani \& Hashim Al-HusseinI, 2013: "Speech Act of Prohibition in English and Arabic: A Contrastive Study on Selected Biblical and Quranic Verses", Arab World English Journal 4 (4), 95-111.

SeARLE, John, 1969: Speech Acts, Cambridge: Cambridge University Press. 
Simpon, Paul, 2004: Stylistics, London and New York: Routledge.

Swan, Michael, 2000: Practical English Usage, International Students Edition, London: Oxford University Press.

THomas, Jenny, 1995: Meaning in Interaction: An Introduction to Pragmatics, London: Longman Group Limited.

WaLES, Katie, 2001 [1989]: A dictionary of stylistics, Harlow: Longman.

WisNiEwski, Kamil, 2007: "Pragmatics" [http://www.anglozof.com/angielski/gramatyka.htm, date of retrieval: November 5, 2017].

\section{Acknowledgment}

The author is very grateful to the University of Mosul / College of Medicine for their provided facilities, which helped to improve the quality of this work. 